\title{
FORMULASI SHAMPO CAIR TRANSPARAN SARI BUAH JERUK NIPIS (Citrus aurantifolia S.)
}

\author{
Fauzia Ningrum Syaputri ${ }^{1}$, Amran Ilyas Tandjung ${ }^{2}$, Faradiba $^{2}$ \\ ${ }^{1}$ Program Studi Farmasi Universitas Muhammadiyah Bandung \\ ${ }^{2}$ Fakultas Farmasi Universitas Muslim Indonesia Makassar \\ Email : fauzia ningrum@yahoo.com; faradiba76@yahoo.com
}

\begin{abstract}
The objective of this research was to determine a stable formula and determine the influence of carbopol enhancing in the preparation of lime extract (Citrus aurantifolia S.) transparent liquid shampoo (TLS). Shampoo made from TLS formulation lime extract in three different concentration of carbopol $10.5 \%: 0.6 \%$ : $0.7 \%)$. Shampoo were then characterized for stability test before and after accelerated storage include organoleptic test, the foam test, test the $\mathrm{pH}$ stability, viscosity measurements, and rheological. The result of organoleptic observation before and after accelerated storage, either formula with concentration of carbopol $0.5 \%, 0.6 \%$, or $0.7 \%$, did not show a change for the color, smell and consistency. There are no differences in foam test from TLS with shampoo preparations comparison. There are no change of PH test in TLS with concentration of carbopol $0.5 \%, 0.6 \%$, or $0.7 \%$ before and after accelerated storage. There are no change of viscosity test in TLS with concentration of carbopol $0.5 \%, 0.6 \%$, or $0.7 \%$ before and after accelerated storage. Third shampoo formula has plastic flow. Formulation of TLS with concentration of carbopol $0.5 \%$ have the most optimal stability than TLS with concentration of carbopol $0.6 \%$ and $0.7 \%$.
\end{abstract}

Keywords: Transparent liquid shampoo (TLS), Citrus aurantifolia S.

\section{PENDAHULUAN}

Jeruk nipis adalah salah satu buah yang dipercaya bisa menghilangkan keberadaan ketombe. Tanaman ini diduga berasal dari daerah India sebelah utara. Begitu pula masyarakat di Amerika Serikat. Mereka mulai mengenal manfaat jeruk nipis sejak zaman Indian kuno. Ohio State Biotechnology Centre di kota Columbus, Ohio, Amerika Serikat, pernah melakukan penelitian terhadap jeruk nipis. Hasilnya, jeruk nipis kaya akan vitamin dan mengandung sejumLah mineral. Kandungan asam dari buah ini dapat melunturkan minyak (sebum) di kulit kepala. Dengan begitu, habitat atau tempat bersarang jamur yang merugikan pun dapat dikurangi. Selain bisa melunturkan sebum di kepala, jeruk nipis juga bisa memberikan efek segar 
dan nyaman terutama bagi kepala berketombe yang kerap dihinggapi rasa gatal. Buah yang kaya dengan kandungan vitamin $\mathrm{C}$ ini juga bisa membuat rambut tampak sehat dan cantik berkilau. ${ }^{1}$

Buahnya mengandung banyak air dan vitamin $C$ yang cukup tinggi. Daun, buah, dan bunganya mengandung minyak terbang. Biasanya jeruk nipis tumbuh dengan baik di daerah dataran rendah yang banyak terkena sinar matahari. Jeruk nipis mengandung asam sitrat, asam amino (triptofan, lisin), minyak atsiri (sitral, limonen, felandren, lemon kamfer, kadinen, gerani-lasetat, linalilasetat, aktilaldehid, nildehid) damar, glikosida, asam sitrun, kalsium, fosfor, besi, belerang vitamin B1dan $\mathrm{C}{ }^{1}$

Secara empiris, jeruk nipis digunakan untuk menghilangkan ketombe dengan cara menggosok kulit kepala dengan buah jeruk nipis secara merata. Namun dengan cara seperti ini, dapat menimbulkan efek samping seperti rasa perih dikulit kepala hingga dapat menimbulkan iritasi. Oleh karena itu, akan dilakukan penelitian tentang pembuatan sediaan farmaseutik yaitu formulasi shampo cair transparan dari sari buah jeruk nipis (Citrus aurantfolia S.) demi kenyamanan pemakaian konsumen untuk menghilangkan ketombe. ${ }^{4}$ Konsentrasi buah jeruk nipis yang digunakan untuk menghilangkan minyak pada kulit kepala sebesar 1 $\%{ }^{5}$

Dalam formulasi shampo cair transparan ini, yang akan divariasikan adalah konsentrasi thickening agent (zat peningkat viskositas) untuk mendapatkan sediaan shampo cair transparan yang stabil. ${ }^{2}$ Bahan peningkat viskositas yang digunakan adalah karbopol. Karbopol digunakan sebagian besar di dalam cairan atau sediaan formulasi semisolid berkenaan dengan farmasi sebagai bahan pensuspensi atau bahan penambah kekentalan. Karbopol bersifat stabil, higroskopik, digunakan sebagai bahan pengental yang baik, viskositasnya tinggi, menghasilkan gel atau larutan yang bening. ${ }^{3}$ Dalam memformulasi shampo cair transparan hal yang paling penting untuk dipertimbangkan adalah titik kabut dan viskositas dari sediaan yang dibuat. ${ }^{7}$

\section{METODE PENELITIAN}

\section{Alat yang digunakan}

Alat-alat yang digunakan pada penelitian yakni batang pengaduk, gelas kimia 250 dan $500 \mathrm{~mL}$ (Pyrex), gelas ukur 10;25;50 mL (Iwaki, Pyrex), lumpang dan alu, penangas air, pot plastik, sendok tanduk, stopwatch, 
Formulasi shampo cair transparan sari buah jeruk nipis (Citrus aurantifolia s.)

Cutter, timbangan analitik (Chya), viskometer brookfield.

\section{Bahan yang digunakan}

Bahan-bahan yang digunakan dalam penelitian yakni air suling, aluminium foil, sari buah jeruk nipis (Citrus aurantifolia S.), karbopol, kertas timbang, kertas saring, natrium lauril sulfat, gliserin, natrium edetat, parfum, $\mathrm{pH}$ Universal, propilen glikol, TEA dan tissue.

\section{Prosedur Penelitian}

\section{Rancangan Formula}

Adapun rancangan formula pada penelitian ini yakni sari buah jeruk nipis (Citrus aurantifolia S.) sebagai zat aktif, natrium lauril sulfat sebagai detergen sekaligus sebagai pembusa, gliserin sebagai emolient dan humektan, karbopol sebagai zat peningkat viskositas yang digunakan dalam tiga variasi konsentrasi, $\mathrm{Na}$ EDTA sebagai bahan sequestrant dan pengkhelat, metil paraben sebagai pengawet, parfum sebagai pengaroma, propilen glikol sebagai kosolvent, TEA sebagai bahan pengembang karbopol dan aquadest sebagai pelarut.

\section{Pembuatan sari buah jeruk nipis}

Buah jeruk nipis (Citrus aurantifolia S.) dipotong menjadi 4 bagian. Diperas buah jeruk nipis, lalu disaring dengan menggunakan kertas saring agar terbebas dari bulir dan bijinya. Setelah itu diukur hasil perasan buah jeruk nipis yaitu sebanyak $1700 \mathrm{~mL}$. Lalu di Frezze dryer hingga diperoleh sebanyak 97,9 gr.

\section{Pembuatan shampo cair transparan} Masukkan natrium lauryl sulfat dalam $30 \mathrm{~mL}$ aquadest, lalu dipanaskan di atas penangas air. Hindari pengadukan yang berlebihan untuk menjaga agar natrium lauryl sulfat tidak berbusa selama pemanasan. Bila natrium lauryl sulfat telah larut, segera ditambahkan sisa air bersama Na-EDTA dan metil paraben lalu diaduk perlahan. Apabila larutan dalam wadah telah jernih, larutan diturunkan dari penangas air. Panaskan $30 \mathrm{~mL}$ aquadest setelah itu masukkan karbopol dan diaduk hingga karbopol larut dan menjadi jernih setelah itu diturunkan dari penangas air. Kemudian ditambah dengan 10 tetes TEA sambil diaduk dengan menggunakan mixer. Setelah karbopol mengembang segera ditambahkan dengan campuran larutan natrium lauryl sulfat, metil paraben dan natrium EDTA diaduk dengan menggunakan mixer hingga homogen. Setelah itu, larutan ditambahkan gliserin dan propilen glikol lalu diaduk perlahan. Setelah homogen ditambahkan sari 
buah jeruk nipis (Citrus aurantifolia S.) sambil diaduk perlahan. Bila semua bahan telah tercampur merata, shampo diberi parfum secukupnya. Shampo didiamkan kurang lebih 24 jam untuk diperoleh kekentalan dan kejernihan optimal yang diikuti oleh penurunan busa. Formulasi dengan karbopol baik pada variasi konsentrasi $0,6 \%$ dan $0,7 \%$, dibuat dengan cara yang sama.

\section{Evaluasi kestabilan shampo}

Sebelum melakukan uji
kestabilan pada shampo cair
transparan dari sari buah jeruk nipis
(Citrus aurantifolia $\mathrm{S}$.) dengan variasi
konsentrasi bahan peningkat
viskositas, diberi perlakuan
penyimpanan dipercepat pada suhu
antara $5^{\circ} \mathrm{C}$ dan $35^{\circ} \mathrm{C}$ masing-masing
12 jam selama 10 siklus. $^{3}$

\section{Pengujian busa}

Dimasukkan shampo cair transparan sebanyak $1 \mathrm{~mL}$ ke dalam gelas ukur $250 \mathrm{~mL}$. Ditambahkan air secara perlahan hingga mencukupi $100 \mathrm{~mL}$. Dilakukan pengocokan ke dua arah, yakni kanan dan kiri selama sepuluh kali. Jalankan stopwatch ketika pengocokan dihentikan. Lalu diukur volume busa dalam gelas ukur dalam beberapa kurun waktu, diantaranya 1,3 , dan 5 menit. Pengujian ini menggunakan sampel pembanding shampo yang telah beredar di pasaran.

\section{Pengujian pH}

Dilakukan pengukuran $\mathrm{pH}$ dalam pengujian stabilitas $\mathrm{pH}$ sebelum maupun setelah kondisi dipercepat. Pengukuran $\mathrm{pH}$ menggunakan kertas $\mathrm{pH}$ Universal.

\section{Pengukuran Viskositas}

Pengukuran viskositas sediaan shampo cair transparan dilakukan sebelum dan setelah penyimpanan dipercepat. Pengukuran dilakukan dengan menggunakan Viskometer Brookfield.

\section{Penentuan aliran}

Sediaan shampo cair transparan yang telah dibuat dituang ke dalam gelas kimia $100 \mathrm{~mL}$. Kemudian diukur viskositas pada berbagai kecepatan (rpm), menggunakan Viskometer Brookfield. Sifat aliran ditentukan dengan membuat grafik hubungan antara shearing stress (tekanan geser) dan rate of shear (kecepatan geser).

\section{HASIL PENELITIAN}

Evaluasi kestabilan dari formula shampo cair transparan dari sari buah jeruk nipis (Citrus aurantifolia S.) dengan berdasarkan variasi konsentrasi bahan peningkat viskositas memberikan hasil sebagai berikut : 
Tabel 1. Rancangan Formula Shampo Cair Transparan Sari Buah Jeruk Nipis (Citrus aurantifolia.S) dengan variasi konsentrasi bahan peningkat viskositas

\begin{tabular}{ccccc}
\hline \multirow{2}{*}{ No. } & Nama bahan & \multicolumn{3}{c}{ Konsentrasi (\%) } \\
\cline { 3 - 5 } & & A & B & C \\
\hline 1. & Sari buah jeruk nipis & 1 & 1 & 1 \\
2. & Na lauril sulfat & 5 & 5 & 5 \\
3. & Gliserin & 10 & 10 & 10 \\
4. & Karbopol & 0,5 & 0,6 & 0,7 \\
5. & Na-EDTA & 0,1 & 0,1 & 0,1 \\
6. & Metil Paraben & 0,2 & 0,2 & 0,2 \\
7. & Parfum (mengandung alkohol & q.s & q.s & q.s \\
8. & denaturasi 50\% dan air) & q.s & q.s & q.s \\
9. & TEA & 15 & 15 & 15 \\
10. & Propilen glikol & Ad 100 & Ad 100 & Ad 100 \\
\hline
\end{tabular}

Tabel 2. Data Pengamatan Organoleptis Sebelum dan Sesudah Penyimpanan Dipercepat

\begin{tabular}{cccc}
\hline \multirow{2}{*}{ Formula } & Jenis Pemeriksaan & \multicolumn{2}{c}{ Kondisi } \\
\cline { 3 - 4 } & Bau & Sebelum & Sesudah \\
\hline \multirow{2}{*}{$\mathrm{A}$} & Warna & Harum & Harum \\
& Konsistensi & Bening & Bening \\
& Bau & Kental & Kental \\
\hline \multirow{2}{*}{$\mathrm{B}$} & Warna & Harum & Harum \\
& Konsistensi & Bening & Bening \\
& Bau & Kental & kental \\
\hline \multirow{2}{*}{ C } & Warna & Harum & Harum \\
& Konsistensi & Bening & Bening \\
& & Kental & Kental \\
\hline
\end{tabular}

Tabel 3. Data Pengukuran Busa Sebelum dan Sesudah Penyimpanan Dipercepat

\begin{tabular}{|c|c|c|c|}
\hline Kondisi & Formula & Durasi (menit) & Volume (mL) \\
\hline \multirow{9}{*}{ Sebelum } & \multirow{3}{*}{$A$} & 1 & 200 \\
\hline & & 3 & 190 \\
\hline & & 5 & 170 \\
\hline & \multirow{3}{*}{$B$} & 1 & 250 \\
\hline & & 3 & 230 \\
\hline & & 5 & 220 \\
\hline & \multirow{3}{*}{ C } & 1 & 250 \\
\hline & & 3 & 240 \\
\hline & & 5 & 230 \\
\hline \multirow{9}{*}{ Sesudah } & \multirow{3}{*}{$A$} & 1 & 220 \\
\hline & & 3 & 205 \\
\hline & & 5 & 179 \\
\hline & \multirow{3}{*}{$B$} & 1 & 220 \\
\hline & & 3 & 200 \\
\hline & & 5 & 180 \\
\hline & \multirow{3}{*}{ C } & 1 & 250 \\
\hline & & 3 & 240 \\
\hline & & 5 & 230 \\
\hline
\end{tabular}


Tabel 4. Data Pengukuran Busa pada Sediaan Pembanding

\begin{tabular}{ccc}
\hline Sampel & Durasi (menit) & Volume $(\mathbf{m L})$ \\
\hline & 1 & 250 \\
D & 3 & 235 \\
& 5 & 220 \\
\hline
\end{tabular}

Tabel 5. Data Pengukuran Stabilitas pH Sebelum dan Sesudah Penyimpanan Dipercepat

\begin{tabular}{cccc}
\hline \multirow{2}{*}{ Kondisi } & \multicolumn{3}{c}{ Nilai pH } \\
\cline { 2 - 4 } & Formula A & Formula B & Formula C \\
\hline Sebelum & 5 & 5 & 5 \\
Sesudah & 5 & 5 & 5 \\
\hline
\end{tabular}

Tabel 6. Hasil Pengukuran Viskositas Sebelum dan Sesudah Penyimpanan Dipercepat

\begin{tabular}{cccc}
\hline Kondisi & $\begin{array}{c}\text { Formula A } \\
\text { (Poise) }\end{array}$ & $\begin{array}{c}\text { Formula B } \\
\text { (Poise) }\end{array}$ & $\begin{array}{c}\text { Formula C } \\
\text { (Poise) }\end{array}$ \\
\hline Sebelum & 8,2 & 8,7 & 9,566667 \\
Sesudah & 8,2 & 8,666667 & 9,566667 \\
\hline
\end{tabular}

Keterangan :
A : Shampo cair transparan dengan konsentrasi 0,5\% bahan peningkat viskositas
B : Shampo cair transparan dengan konsentrasi 0,6 \% bahan peningkat viskositas
C : Shampo cair transparan dengan konsentrasi $0,7 \%$ bahan peningkat viskositas
D : Shampo cair transparan merek Herbal essences dengan Camellia hot oil

\section{PEMBAHASAN}

Jeruk nipis adalah salah satu buah yang secara empiris dipercaya bisa menghilangkan keberadaan ketombe. Buahnya mengandung banyak air dan vitamin C yang cukup tinggi. Jeruk nipis mengandung asam sitrat, asam amino (triptofan, lisin), minyak atsiri (sitral, limonen, felandren, lemon kamfer, kadinen, gerani-lasetat, linali-lasetat, aktilaldehid, nildehid) damar, glikosida, asam sitrun, kalsium, fosfor, besi, belerang vitamin B1dan $\mathrm{C}{ }^{1}$
Secara empiris, jeruk nipis digunakan untuk menghilangkan ketombe dengan cara memotong sebuah jeruk nipis menjadi 2-4 bagian. Gunakan untuk menggosok kulit kepala secara merata. Biarkan mengering beberapa lama, baru dibilas. Namun dengan cara seperti ini, dapat menimbulkan efek samping seperti rasa perih dikulit kepala hingga dapat menimbulkan iritasi. ${ }^{4}$ Oleh karena itu, akan dilakukan penelitian tentang pembuatan sediaan farmaseutik modern yaitu formulasi shampo cair transparan dari sari buah 
jeruk nipis (Citrus aurantfolia S.) demi kenyamanan pemakaian konsumen untuk menghilangkan ketombe. Dalam formulasi shampo cair transparan ini, yang akan divariasikan adalah konsentrasi thickening agent (zat peningkat viskositas) untuk mendapatkan sediaan shampo cair transparan yang stabil. Dimana diketahui bahwa dalam memformulasi shampo cair transparan hal yang paling penting untuk dipertimbangkan adalah titik kabut dan viskositas dari sediaan yang dibuat. ${ }^{7}$

Formulasi shampo cair transparan dibuat dengan memvariasikan konsentrasi bahan peningkat viskositas yaitu 0,5\%, 0,6 \% dan $0,7 \% .^{8-9}$ Bahan peningkat viskositas yang digunakan dalam formulasi shampo cair transparan adalah karbopol, karena bersifat hidrofil sehingga mudah terdispersi dalam air dan dapat menghasilkan larutan yang jernih. ${ }^{3} \quad$ Untuk mengembangkan karbopol, harus dinetralkan dengan basa yaitu TEA. Semakin tinggi konsentrasi karbopol yang akan dibuat, maka akan semakin banyak pula TEA yang dicampurkan kedalam karbopol untuk menghindari sifat karbopol yang cenderung kembali asam. ${ }^{6}$
Setelah dibuat tiga formula dengan konsentrasi bahan peningkat viskositas yang berbeda, dilakukan pengujian kestabilan berdasarkan lima parameter pada kondisi sebelum dan setelah penyimpanan dipercepat, diantaranya pemeriksaan organoleptis, uji busa, pengukuran $\mathrm{pH}$, pengukuran viskositas, dan penentuan nilai yield. Pengujian kestabilan dilakukan dengan metode kondisi dipaksakan (stress condition) dengan penyimpanan pada suhu $5^{\circ} \mathrm{C}$ dan $35^{\circ} \mathrm{C}$ selama 10 siklus, masing-masing siklus berdurasi 12 jam. Tujuan dilakukannya kondisi dipaksakan (penyimpanan dipercepat) adalah untuk mempercepat proses peruraian dari bahan-bahan dan untuk mempersingkat waktu pengujian.

Pemeriksaan organoleptis dilakukan untuk mengetahui ada tidaknya pengaruh penyimpanan pada warna, bau, dan konsistensinya. Adapun hasil pengamatan yang diperoleh dari ketiga formula shampo cair transparan dari sari buah jeruk nipis (Citrus aurantifolia S.), sebelum atau sesudah penyimpanan dipercepat, baik formula dengan konsentrasi pengental $0,5 \%, 0,6 \%$, maupun $0,7 \%$, tidak memperlihatkan perubahan baik dari segi warna, bau, maupun konsistensi sediaan. 
Pengujian busa dilakukan untuk melihat kekuatan pembusaan dari shampo cair transparan dari sari buah jeruk nipis (Citrus aurantifolia S.), karena shampo harus memiliki busa yang baik demi kenyamanan pemakaian konsumen. Adapun hasil yang diperoleh dari uji busa shampo yang telah diformulasi dengan sediaan shampo pembanding, yakni tidak terdapat perbedaan yang jauh dari busa sediaan shampo yang diformulasi pada tiap konsentrasi dengan sediaan pembanding.

Pengukuran $\mathrm{pH}$ dari sediaan shampo harus dilakukan sebelum maupun setelah kondisi dipercepat. $\mathrm{pH}$ pada shampo dapat ditoleransi pada range 5-9. Kertas $\mathrm{pH}$ universal adalah media yang digunakan dalam pengukuran $\mathrm{pH}$ sediaan shampo cair transparan dari sari buah jeruk nipis (Citrus aurantifolia S.). Adapun hasil yang diperoleh yaitu formula $A$, formula $\mathrm{B}$ dan formula $\mathrm{C}$ memiliki $\mathrm{pH}$ 5 dan tidak mengalami perubahan $\mathrm{pH}$ baik sebelum dan sesudah penyimpanan dipercepat.

Viskometer

Brookfield digunakan untuk mengukur viskositas dari sediaan shampo cair transparan dari sari buah jeruk nipis (Citrus aurantifolia S.). Viskositas sediaan diukur menggunakan spindle no. 64 dengan kecepatan 50 rpm sebanyak tiga kali replikasi.

Dari data yang diperoleh, dilakukan analisa secara statistik dengan menggunakan metode "Rancangan Acak Kelompok". Hasil analisis menunjukkan bahwa viskositas dari formula $A$, formula $B$, dan formula $C$ mengalami perubahan yang sangat signifikan. Kemudian dilakukan uji lanjutan menggunakan uji lanjutan BNJ (Beda Nyata Jujur) karena nilai koefisien keseragaman dibawah 5\% yakni 1,535735048 \%.

Pada uji lanjutan BNJ, diperoleh hasil yakni pada formula $A$, formula $B$ dan formula $C$ tidak mengalami perubahan yang nyata (non signifikan) pada kondisi sebelum maupun sesudah penyimpanan dipercepat.

Parameter terakhir yang dilakukan pada pengujian kestabilan adalah penentuan nilai yield dari sediaan shampo cair transparan dari sari buah jeruk nipis (Citrus aurantifolia S.). Nilai yield dihitung dari pengukuran viskositas sediaan pada beberapa rpm, kemudian dari data yang diperoleh dapat ditentukan Shearing stress (tekanan geser) dan Rate of shear (Kecepatan geser), hingga kemudian dapat dihitung nilai yieldnya. Sifat aliran dapat ditentukan dengan membuat grafik hubungan 
antara Shearing stress (tekanan geser) dan Rate of shear (Kecepatan geser). Melalui hasil analisa data statistik menunjukkan perubahan yang sangat signifikan pada ketiga formula sebelum dan sesudah penyimpanan dipercepat. Kemudian dilakukan uji lanjutan menggunakan uji lanjutan DUNCAN karena nilai koefisien keseragaman lebih dari $10 \%$ yaitu $14,66935741 \%$.

Pada uji lanjutan DUNCAN, diperoleh hasil yakni pada formula $A$ mengalami perubahan yang non signifikan pada kondisi sebelum maupun sesudah penyimpanan dipercepat. Sedangkan pada formula B mengalami perubahan yang signifikan pada kondisi sebelum maupun sesudah penyimpanan dipercepat. Pada formula C mengalami perubahan yang sangat signifikan pada kondisi sebelum maupun sesudah penyimpanan dipercepat.

Setelah dibuat rheorogram, hubungan antara Shearing stress (tekanan geser) dan Rate of shear (kecepatan geser), diperoleh sifat aliran non newton yaitu aliran plastis. Cairan yang mempunyai aliran plastis tidak akan mengalir sebelum suatu gaya tertentu dilampauinya. Gaya tersebut adalah Nilai Yield.
Dari hasil pengujian dengan kelima parameter yang telah dilakukan maka shampo cair transparan sari buah jeruk nipis (Citrus aurantifolia S.) formula A dengan konsentrasi $0,5 \%$ bahan peningkat viskositas pada sediaan memiliki kestabilan yang optimal.

\section{KESIMPULAN}

Dari hasil pengujian dengan kelima parameter yang telah dilakukan maka dapat disimpulkan bahwa shampo cair transparan sari buah jeruk nipis (Citrus aurantifolia S.) yang memiliki kestabilan optimal adalah formula A dengan konsentrasi 0,5\% bahan peningkat viskositas.

\section{DAFTAR PUSTAKA}

1. Anonim. Jeruk nipis (Citrus aurantifolia S) (Online), http://jeruknipis.files.wordpress.co $\mathrm{m} / 2009 / 04 / . \mathrm{pdf}$, diakses tanggal 2 Oktober 2010.

2. Balsam MS. Cosmetics Science and Technology. John Wiley Co; New York:1972.

3. Banker, Gilbert S. Modern Pharmaceutics Fourth edition, Revised and Expanded. Marcel Dekker Inc; New York: 2002

4. Dalimartha, Setiawan. Atlas Tumbuhan Obat Indonesia Jilid 2. Trubus Agriwidya. Jakarta, 2007.

5. Ernest W, Flick. Cosmetic and Toiletry Formulation. Noyes Publication : USA, 1989. 
6. Gennaro, Alfonso R. Remington: The Science and Practice of Pharmacy $20^{\text {th }}$ edition, Philadelphia College of Pharmacy and Science: Philadelphia, 2000.

7. Jellineck, Stephan J. Formulation and Function of Cosmetics. New York, 1970.
8. Keithler WM. The Formulation of Cosmetic and Cosmetic Specialties. Drug and Cosmetic Industry : New York, 1997.

9. Rowe, Raymond C, Sheskey, Paul, Owen, Sian C. Handbook of Pharmaceutical Excipients Ebook,. Pharmaceutical Press and American Pharmacists Association 2004:USA,2004 